\title{
The Relationship between Organizational Capability, Organizational Learning and Financial Performance*
}

\author{
Lela HINDASAH ${ }^{1}$, Nuryakin NURYAKIN ${ }^{2}$
}

Received: May 05, 2020 Revised: June 07, 2020 Accepted: July 07, 2020

\begin{abstract}
This study aims to empirically investigate the influence of organizational capability and organizational learning on the financial performance of family-business type small- and medium-sized enterprises (SMEs). In addition, this study examines the moderating role of SMEs' ages and the managers' experiences in the relationship between organizational capability and organizational learning on the SMEs financial performance. This study is a basic exploratory research conducted by using an empirical survey, i.e., sampling of the businessman (the owner) of family-business type SMEs cross-functional in the area of DIY. The study uses purposive sampling. The respondents are the SME businessmen from the various business sectors in Yogyakarta, Indonesia. The number of respondents is 150. Hypothesis testing used SPSS program's moderation regression approach; validity and reliability testing used confirmatory factor analysis and Cronbach's alpha. The result of this study shows that organizational capability positively and significantly affects the financial performance. Also, organizational learning significantly affects the financial performance. The organization's age factor does not moderate the relationship between organizational capability and the financial performance, but it is significant on the organizational learning. The factor of manager's experience moderates insignificantly on the relationship between organizational capability and financial performance. However, it is significant to the organizational learning.
\end{abstract}

Keywords: Organizational Capability, Organizational Learning, Manager Experience, SMEs, Financial Performance

JEL Classification Code: M12, M21, M31

\section{Introduction}

The development of small- and medium-sized enterprises (SMEs) encourages economic growth. SMEs have a strategic

\footnotetext{
*Acknowledgements:

We sincerely are thankful for the funding research from LP3M (Lembaga Penelitian, Publikasi dan Pengabdian Masyarakat) Universitas Muhammadiyah Yogyakarta for endorsing the grand research project in completing the survey for SMEs Family type business owner or manager.

${ }^{1}$ First Author. Management Department, Economics and Business Faculty, Universitas Muhammadiyah Yogyakarta, Indonesia. Email: lela.hindasah@gmail.com

${ }^{2}$ Corresponding Author. Associate Professor, Management Department, Economics and Business Faculty, Universitas Muhammadiyah Yogyakarta, Indonesia [Postal Address: Brawijaya Road, Bantul, Yogyakarta City, 55183, Indonesia] Email: nuryakin@umy.ac.id

(c) Copyright: The Author(s)

This is an Open Access article distributed under the terms of the Creative Commons Attribution Non-Commercial License (http://Creativecommons.org/licenses/by-nc/4.0/) which permits unrestricted noncommercial use, distribution, and reproduction in any medium, provided the original work is properly cited.
}

role in the Indonesian economic growth. They have a role in the national economic growth, the creation of gross domestic product (GDP), national value added, and employment. The existence and the role of the SMEs are influential to the regional, national as well as global economies. However, most of the SMEs (especially in the developing countries) face a basic problem: they are run traditionally and in hereditary fashion. The SMEs are weak on their management and haven't able yet to anticipate the environmental changes because of their limited innovation. Several research shows that SMEs have not had an eligible organizational ability (Martinez, Radnor, Garengo, \& Bernardi, 2007). Even more, it is only a small part of SMEs that is oriented on the growth as they have limited access to suppliers.

The study about the SMEs showed that they lack key factors, which determine the success of an SME. Several studies found that the success of the businessmen's influence and the others explain the importance of external factors or the factors that come from the outside (such as economic conditions, government policy, financial support and natural form, and the infrastructure). However, studies explain that 
the businessmen as the owner play an important role in deciding the business' excellence.

Holtzman (2008) found that active family ownership positively affects the profitability. Other studies also explain the factors that influence the firm performance. Marketing capabilities influence the marketing planning and pricing, and it positively affects the firm performance (Mohd Taisir Masadeh, Mohammad Maqableh, \& Karajeh, 2014). Emadzade, Mashayekhi, and Abdar (2012) found that the company implementing organizational practice tends to offer consistency support to their knowledge management as an aspect, which can improve the company's performance. The effect of the knowledge management has a significant relationship between the resources and the organization's performance. That study also showed that some of the resource knowledge (for example the structure of the organization, knowledge implementation) relates directly to the organization's performance.

Tseng and Lee (2014) conducted a study of the senior managers of the SMEs (in the industries of services, technology, and manufacture). In they study, Tseng and Lee (2014) measured the effectivity of management ability and dynamic ability to improve the business performance. The result showed that the management ability affects the dynamic ability and finally affects the organizational performance. Tseng and Lee (2014) also measured the indicator effect of the dynamic ability (the ability of sensing and the ability to integrate) to the performance. And the result showed that both sensing ability and the ability to integrate have a positive and significant influence on the performance.

Chang and Wang (2013) explained the important factors of the success of the organization in improving its business. Those important factors, among others, are (1) organization and management process, which are the methods and habits related to the things, the lesson, and the implementation of a model; (2) organization's position, where the strategic role of a company depends on certain organization process and assets including real assets and intangible assets (for example technique), complementary assets, financial assets, reputation assets, structural assets, assets system, and market assets; and (3) strategic development, being the dependency strategy in which the company develops the ability and the function of the company.

This study will be conducted with family-business type SMEs. The characteristics of family business SMEs are interesting to be studied because this organization has unique management (Raza Bilal, Naveed, \& Anwar, 2017). The existence of the SMEs run as a family business has already been studied by the researchers (Brines, Shepherd, \& Woods, 2013; Hiebl, 2015; Pérez-Cabañero, Camra-Fierro, González-Cruz, \& Cruz-Ros, 2012; Wang, Watkins, Harris, $\&$ Spicer, 2004). The study conducted by Brines et al. (2013) emphasizes the importance of the innovative attitudes of the owners in improving their performance.

Related to the effort of the improvement of the SMEs performance run as a family business, this study focuses on the analysis of the influence of organizational capability and organizational learning on the financial performance of family business SMEs. Furthermore, this study also examines the moderating role of SMEs' age and the manager's (owner) experiences in the relationship between organizational capability and organizational learning on the SMEs financial performance.

\section{Theoretical Review and Hypotheses}

\subsection{The Relationship of Organizational Capability on Financial Performance}

Ability is the strategic role of the organization in achieving performance. Furthermore, some researchers argued that the capability to the organization is a special resource (Prahalad \& Hamel, 1994), special knowledge (Day, 1994), superior resource (Hunt \& Morgan, 1995), and strategic assets (Barney, 1991) to the organization. The successful organization, according to Morgan, Slotegraaf, and Vorhies (2009) is decided by the capability and unique resource compared with its competitors. Organizational capability can be interpreted as the ability of an organization to manage its business with the sensitivity to respond to rapid environmental changes, able to reduce the organizational operational activities, and responding the changes of environment and market globalization (Garengo \& Bernardi, 2007).

Freeze and Kulkarni (2007) found that organizational capability is related to the tangible knowledge assets. This research's result showed the need of organization responsibility to use processes and technology provided by the organization as a framework to create a responsible human resource to benefit the knowledge in an organization, process, and technology needed to improve organization knowledge ability, effectively. This research also identified five abilities in the company's management in the forms of skills, learning, policy and procedure, data, and knowledge document have a casual relationship with the identified actions in the company performance.

Ong, Ismail, and Goh (2010) said that the SMEs' businessman must have a responsibility to ensure the survival and the success of the organization's management. In addition, the flexibility in the operation and the ability to adapt to the changes and the SMEs ability will be influenced by the uncertain conditions. This research result explained that entrepreneurship and the SMEs play an important role in influencing SMEs' competitive advantage and affecting the SMEs performance. Other researchers, such as Singh and 
Garg (2008), stated that SMEs have not received the attention to develop their effective strategy in the past. The SME faces many obstacles because of the lack of resources and the low innovative ability. To maintain their competitiveness, SMEs should have an assets standard, organizational process, and best performance achievement. Meanwhile, Chew, Yan, and Cheah (2008) concluded that competence and strategy influence SMEs in achieving performance. In addition, there is a positive relationship between the ability and competitive strategy. This research result also found the need for the company's effort in aligning capabilities and strategy to reach the best performance.

Emadzade et al. (2012) found that, although the company has already implemented knowledge management, the organization needs to consistently support the knowledge management in improving the company's performance. The effect of knowledge management has a significant relationship with the resources and the organization's performance. Lee, Lee, and Penning (2001) examined the internal and external network ability on the company performance. Internal ability was operationalized on the orientation of entrepreneurship, technology ability, and invested financial resource. The research result showed that the internal ability dimension affects the performance in innovation. The interaction between internal ability and the relationship based on cooperation has a significant influence on the performance. Meanwhile, Lawson-Body and O'Keefe (2006) empirically proved that the organizational ability based on the information system could bring strategic benefits through the customer's loyalty on SMEs. The result of this research also showed that the Internet affects the interorganizational relationship (IOR) between SMEs and their loyal customers.

Carvalho and Reis (2012) examined the role of organizational capabilities through the information technology ability in analyzing the manager's view about the creativity technique implementation, and the company's relationship, which used information technology that succeeds in placing the innovative product in the market. The research result found that an organization contributes to the idea and finally to the launch of the innovative products in the market. The study with the same result was also conducted by Jamsa, Tahtinen, Ryan, and Pallari (2011). It showed that SMEs used their network as a source of changes and resources, and their network can function as a path to changes leading to the sustainable advantage. This study also found the important role of SME in developing the skills (for example the willingness to solve problem), on one hand, to help them to benefit the network as a source of changes and resources. And on another hand, it influences the network to develop their sustainable advantage. C.-C. Chang (2012), in another study, examined the company oriented to the market sensitivity, the ability to absorb the knowledge, social network ability, and interrogative ability to communicate and negotiate. It is the dynamic ability in the organization that IT company needs in increasing the financial performance. Based on the explanation of the previous studies, the hypothesis that can be developed is follows.

H1: Organizational capability positively affects the SMEs'financial performance.

\subsection{The Relationship of Organizational Learning on Financial Performance}

Organizational learning is the organization process in creating, transferring, integrating the knowledge and skills, and learning in the business interaction process (Tohidi, Seyedaliakbar, \& Mandegari, 2012). Michna (2009)) examined the relationship of cross-cultural management within the company and organizational learning in the organization performance. There is a correlation to the organizational learning. The dimension of the organizational learning correlates with the organization performance. Eris and Ozmen (2012) found that organizational learning influences the company's performance. The research by Eris and Ozmen (2012) gave a clear proof about the role of market orientation, organizational learning and the innovation toward the company's performance.

Kropp, Lindsay, and Shoham (2006) empirically proved the relation among entrepreneurship orientation, marketing activity, and organizational learning to the entrepreneurial performance at international business companies. The result showed that there is a positive relationship between innovation, market orientation, and organizational learning and the business performance (Nuryakin, 2018). Besides the innovation, which affects the company, the role of organizational learning also brings a contribution toward the performance. Kropp et al. (2006) examined the relationship between entrepreneurship, marketing, and organizational learning on the entrepreneurial performance of the international business company. The result showed that there is a positive relationship between innovation, market orientation, and organizational learning and the international business performance. Mavondo, Chimhanzi, and Stewart (2005) showed that the result of orientation learning, customer's orientation, and the role of human resource positively influence the company's performance. Therefore, relationship can be achieved in the company's performance (Nuryakin \& Ardyan, 2018).

Lin and Peng (2008) explained that the definition of 'performance' is the result of the business process and the activity of organization's operations, including the achievement of company's purpose both internal and external. 'Performance' in other researcher's view is 
defined as an important thing for the company with the right approach and criteria in achieving the sustainable competitive advantage. In the study conducted by Yildız and Karakaş (2012), performance is measured with eleven indicators. These indicators are, among other, profit and profit increase, sales and sales growth, market share and the increase of market share, the success of new product launching, all the business performance, return on sales, return on investment, customers' satisfaction, procurement of good quality of goods/services, reputation and image, and competitive advantage (Nuryakin, Widowati, \& Fatmawati, 2018). Based on the explanation above, the following hypothesis is developed:.

H2: Organizational learning positively influences the SMEs'financial performance

\subsection{Moderating Variable}

The testing of the effect of the relationship between organizational capability and organizational learning toward the financial performance has been conducted by inserting the variable of moderating age and experience of the manager. The firm age and manager experience are the determinants of financial performance of an organization. A large body of empirical research has been conducted about the important role of organizational capability and organizational learning in reaching the best financial performance (Mikhailitchenko \& Lundstrom, 2006; Salim \& Sulaiman, 2011; Sony \& Naik, 2011; Stata, 1989). The sampling methods of this research used purposive sampling, based on the experience of the managers or owners of SMEs. Therefore, the firm's age and manager's experience were included as a control variable, exploring this relationship in the light of empirical data. Based on the literature review and the previous research, the empirical research model was developed as follows (see Figure 1)

\section{Research Methods}

This study is a basic exploratory research. It was conducted by using an empirical survey, i.e., the sampling of the businessman (the owner) family-business SMEs cross-functional in the area of DIY. This study focuses on the organizational capability and organizational learning in increasing the financial performance. This research focuses specifically on the performance attained by the owner of SMEs in the area of DIY. The hypothesis testing was carried out by using the moderation regression approach with SPSS program. The model testing was conducted using a measurement model to examine the construct of organizational capabilities, organizational learning, and financial performance. The indicators build the construct by considering the parameters obtained from the hypothesis testing.

\subsection{Scale and Measurement}

The organizational capability is the ability of an organization to respond to the environmental change, product lifecycle reduction, relocating the organization's operational activities, responding to the environmental change and global market (Garengo \& Bernardi, 2007). The question items used in measuring the organizational capability used six indicators, i.e., the use of technology (computer) in finishing work, the election of potential people to develop the organization, the involvement of the customers in developing the business, the involvement of the supplier in business process, the discovery of creative ideas in order to develop the business, and the coordination with all the units.

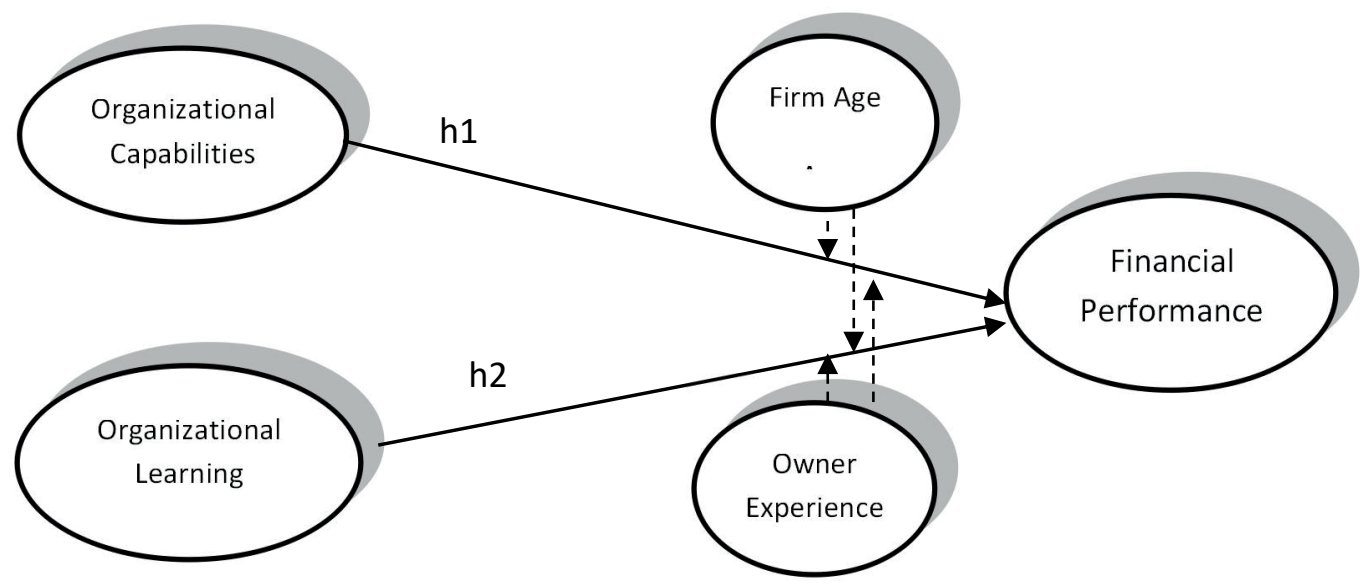

Figure 1. The Research Model 
Table 1: Descriptive Statistics

\begin{tabular}{|c|c|c|}
\hline & Number & Percent \\
\hline \multicolumn{3}{|l|}{ (I) Firm Industry } \\
\hline CV & 26 & $17,3 \%$ \\
\hline Ltd & 22 & $14,7 \%$ \\
\hline Personal company & 98 & $65,3 \%$ \\
\hline Other & 4 & $2,7 \%$ \\
\hline \multicolumn{3}{|c|}{ Number of employees } \\
\hline$<25$ & 129 & $86,0 \%$ \\
\hline $26-50$ & 6 & $4,00 \%$ \\
\hline $51-75$ & 1 & $0,7 \%$ \\
\hline $76-100$ & 1 & $0,7 \%$ \\
\hline$>100$ & 13 & $8,7 \%$ \\
\hline \multicolumn{3}{|l|}{ Age (years) } \\
\hline $1-3$ & 56 & $37,3 \%$ \\
\hline $4-6$ & 39 & $26,0 \%$ \\
\hline $7-10$ & 28 & $18,7 \%$ \\
\hline$>10$ & 27 & $18,0 \%$ \\
\hline \multicolumn{3}{|l|}{ (II) Personal } \\
\hline \multicolumn{3}{|l|}{ Age (years) } \\
\hline$<25$ & 78 & $52,0 \%$ \\
\hline $26-30$ & 37 & $24,7 \%$ \\
\hline $31-35$ & 14 & $9,3 \%$ \\
\hline $36-40$ & 12 & $8,00 \%$ \\
\hline $41-45$ & 6 & $4,00 \%$ \\
\hline$>45$ year & 3 & $2,00 \%$ \\
\hline \multicolumn{3}{|l|}{ Gender } \\
\hline Male & 93 & $62 \%$ \\
\hline Female & 57 & $38 \%$ \\
\hline \multicolumn{3}{|l|}{ Respondent job title } \\
\hline Owner & 21 & $14 \%$ \\
\hline Manager & 33 & $22 \%$ \\
\hline Owner and manager & 96 & $64 \%$ \\
\hline \multicolumn{3}{|l|}{ Education level } \\
\hline Elementary school & 1 & $0,7 \%$ \\
\hline Junior high school & 8 & $5,3 \%$ \\
\hline Diploma & 63 & $42,0 \%$ \\
\hline Undergraduate & 58 & $38,7 \%$ \\
\hline Postgraduate & 13 & $8,7 \%$ \\
\hline Other & 7 & $4,7 \%$ \\
\hline
\end{tabular}

These indicators were measured with a 5-point Likert scale, with 1 being "strongly disagree" and 5 "strongly agree" (see Table 1).

The organizational learning in this research is described as the process developed by the organization in creating, transferring and integrating the knowledge and expertise, the process of learning and business interaction (Tohidi et al., 2012). The question items to measure the organizational learning used six indicators, i.e., strong commitment to change, the open attitude to suggestions, sharing information, interact openly, and dare to take risks. These indicators were measured with a 5-point Likert scale, with 1 being "strongly disagree" and 5 "strongly agree".

The definition of financial performance according to Jaakkola, Möller, Parvinen, Evanschitzky, and Mühlbacher (2010) is the steps of the company in reaching the financial purpose such as margin profit and return on investment. The financial performance is measured with six indicators, i.e., corporate profits, volume of assets, volume of capitals, volume of sales growths, and cash flow. These indicators were measured with a 5-point Likert scale, with 1 being "strongly disagree" and 5 "strongly agree".

\subsection{Validity and Reliability Testing}

The validity and reliability testing on the research instrument (questioner item) in this research used confirmatory factor analysis to examine the construct relationship and its indicators (questionnaire validity). At the same time, the reliability testing was using Cronbach's alpha. The result of the testing of confirmatory factor analysis and Cronbach's alpha are provided as follow (see Table 2). The statistical testing to decide the value of validity and reliability of the third construct, i.e., organizational capability, learning organizational, financial performance, resulting in the value of loading factor $>0.05$ and construct reliability $>0.6$. Therefore, it can be concluded that the instrument in measuring the variables is valid (see Table 2).

\section{Results}

The result of the testing on mean, value of standard deviation and matrix trading among organizational capability variable, organizational learning, and financial performance can be seen in Table 3. There are two hypotheses in this research. The testing of the model in the hypothesis used the advanced statistic testing with the approach of multiple regression analysis and role testing of moderating variable. The approach to test the hypotheses is described in Table 4. By using the value of statistical testing with SPSS program on the value testing, which is appropriate to the statistical assumptions, it can be described that these values fulfill 
Table 2: Scale item for measures

\begin{tabular}{|c|c|}
\hline Reflective scale (measured on 1 - 5 point Likert Scale) & $\begin{array}{c}\text { Standardized factor } \\
\text { loading }\end{array}$ \\
\hline $\begin{array}{l}\text { Organizational Capability (Cronbach's } \alpha=0.685 \text { ) } \\
\text { - We are using the technology (computer) in finishing our work. } \\
\text { - We choose potential people in developing the organization. } \\
\text { - We involve the customers in developing the business process } \\
\text { - We involve supplier in our business process. } \\
\text { - We find the creative idea in developing the business. } \\
\text { - We coordinate with every unit in the planned schedule. } \\
\text { Learning Organizational (Cronbach's } \alpha=0.744 \text { ) } \\
\text { - We have a strong commitment to being the best. } \\
\text { - We open attitude to the suggestions in order to develop the organization. } \\
\text { - We share the important information about the organization to all of the units in the } \\
\text { - } \text { - We openization. } \\
\text { - We dare to take a business risk in the middle of environmental uncertainty. } \\
\text { Financial Performance (Cronbach's } \alpha=0.946 \text { ) } \\
\text { - The profit of the company has increased in the last three years. } \\
\text { - The number of the asset (property) of our company has increased in the last three years. } \\
\text { - The number of working capitals has increased in the last three years. } \\
\text { - The number of cash flow has increased in the last three years }\end{array}$ & $\begin{array}{l}0.555 \\
0.650 \\
0.640 \\
0.571 \\
0.649 \\
0.723 \\
\\
0.722 \\
0.743 \\
0.735 \\
\\
0.753 \\
0.617\end{array}$ \\
\hline
\end{tabular}

Table 3: Descriptive Statistics and Correlations

\begin{tabular}{|c|c|c|c|c|c|c|}
\hline & Mean & $\begin{array}{l}\text { Standard } \\
\text { Deviation }\end{array}$ & 1 & 2 & 3 & 4 \\
\hline Age & 7.75 & 9.323 & 1.000 & & & \\
\hline Owner experience & 4.92 & 4.678 & $.025^{* * *}$ & 1.000 & & \\
\hline Organizational capabilities & 25.12 & 3.499 & -.063 & -.050 & 1.000 & \\
\hline Organizational Learning & 20.55 & 3.031 & -.115 & -.022 & $.516^{\star * *}$ & 1.000 \\
\hline Financial Performance & 18.68 & 4.144 & .006 & .066 & $.324^{\star * *}$ & $0.462^{* * *}$ \\
\hline
\end{tabular}

${ }^{*}$ Correlation is significant at the $p<0.1$ level (2-tailed). ${ }^{* *}$ Correlation is significant at the $p<0.05$ level (2-tailed).

*** Correlation is significant at the $p<0.01$ level (2-tailed).

the specified cut-off value. This indicates that the model of research is accepted and met the required standard.

The correlation between organizational capability and financial performance shows a significant correlation $\left(0.324^{* *}\right)$. The relationship between the variable of organizational learning and financial performance shows less accurate correlation number $(0.462 * *)$. Based on the founding mentioned before, it can be concluded that both variables have strong relations with the financial performance (see Table 4). Table 4 explains the t value and significance of the relationship among organizational capability, organizational learning, and financial performance. Furthermore, this research will also be displayed in Table 4, which examines each hypothesis.

The organizational capabilities significantly impact the financial performance. Table 4 shows the result of multiple regression testing on the model of the relationship of organizational capabilities toward financial performance, i.e., the $t$ value $(4.172<1.96)$ with significant value $(0.000$ $<0.10)$. Therefore, the hypothesis, which mentions that the organizational capability has a positive impact on financial performance, is proven. Then, hypothesis 1 is accepted. 
Table 4: Results of the Hypothesis Testing

\begin{tabular}{|l|c|c|c|c|}
\hline \multicolumn{1}{|c|}{ Variable Interaction } & Coefficient & t Value & t sig & Result \\
\hline Organization Capabilities & 0.324 & 4.172 & $0.00^{* * *}$ & Accepted \\
\hline Organizational Learning & 0.632 & 6.342 & $0.00^{* * *}$ & Accepted \\
\hline Moderating & 0.087 & 1.059 & 0.291 & Rejected \\
\hline Organization Capabilities *Age & 0.144 & 1.766 & $0.080^{*}$ & Accepted \\
\hline Organizational Learning * Age & -0.041 & 0.502 & 0.617 & Rejected \\
\hline Organization Capabilities * Owner experience & 0.170 & 2.095 & $0.038^{* *}$ & Accepted \\
\hline Organizational Learning * Owner experience &
\end{tabular}

Note: *Significant at $p \leq 0.10$; if $(t) \geq 1.96$

The organizational learning significantly impacts the financial performance. Table 4 shows the result of the relationship of organizational learning on financial performance, which is represented by the value of $(\mathrm{t}=$ $6.342>1.96)$ and the significant value of $(0.000<0.05)$. Therefore, the hypothesis, which mentions that the organizational learning has a positive impact on financial performance, is proven. Then, hypothesis 2 is accepted.

The age of the organization does not moderate the relationship of organizational capability on financial performance. The result of moderation regression testing can be seen from the $t$ value $(t=1.059<1.96)$ and the significant value of $0.291>0.05$. In contrast, the age of organization moderates the relationship of organizational learning on financial performance, which can be seen from the $t$ value $(t=1.766>1.96)$ and the significant value of $0.080>0.10$.

The experience of the manager cannot moderate the relationship of organizational capability on financial performance. The result of moderation regression can be seen from the $t$ value $(t=0.502<1.96)$ and significant value of $0.617>0.05$. In another way, the age of organization moderates the relationship of organizational learning on financial performance which can be seen from $\mathrm{t}$ value $(\mathrm{t}=$ $2.095>1.96$ ) and significant value of $0.080>0.038$.

\section{Findings and Discussion}

This research examines the effect of organizational capability and organizational learning on the financial performance of family-business type SMEs. Moreover, this study also examines the role of moderation in the age of SMEs and the experience of the manager (owner) of SMEs in the relationship of organizational capability and organizational learning with the financial performance of SMEs.

The first finding of this study explains that the organizational capability significantly affects the financial performance. This study supports the previous study that was conducted by Freeze and Kulkarni (2007), which stated that organizational capability consists of the dimension of the company management capability in creating the expertise, learning, policy, and procedure, data and document, which has a causal relationship with the actions that has been identified in the company performance. The results by Ong et al. (2010) also supports this study, which stated that the SME businessmen have to have the responsibility to ensure the life sustainability and success of organizational management.

Other researchers who also concur are Singh and Garg (2008), who mentioned that SMEs need to maintain their competitiveness and have the property standard, organizational process, and advanced performance achievement. Chew et al. (2008) also support this study and concluded that the importance of SMEs to have competence and strategy affects the SMEs in achieving the performance.

The second finding of this study explains that the organizational learning significantly affects the financial performance. This finding supports the study by Mishna (2009), who discovered that the organizational learning correlates with the organizational performance. Likewise, the study by Eris and Ozmen (2012) prove the important role of organizational learning and innovation on company performance. The research result by Kropp et al. (2006) also found that the organizational learning affects the entrepreneurship performance on the international business company. Moreover, another study also shows the existence of a positive relationship between innovation, market orientation, and organizational learning on international business performance (Mavondo et al., 2005). Lin and Peng (2008) also found that the company performance in the view of other researchers is interpreted as something important for the company with an appropriate approach and criteria in achieving the sustainable competitive advantage through the process of transfer and learning.

\section{Limitations and Future Research}

The interesting finding of this study indicates that it is important for the family-business type SMEs to develop their 
organization and use an organizational learning process. The owner of these types of SMEs needs to continuously develop the organizational capabilities through the technology (computer) in completing the works. They need to choose potential human resources in developing the organization, involving the customer in building the business process, involving the suppliers in the business process, finding the creative ideas in building the business process, and coordinate with each part of the company.

This study recommends the need of strengthening the organizational capabilities through the strategic role of the owner of family-business type SMEs in fulfilling the customer's demand, responding to competitor's movement, and implement the knowledge sharing with all the elements of the organization. One effort that needs to be done is to actively respond to what customer's want, but still pay attention to the unique product value.

Future study should use a more comprehensive development model about the internal characteristic from the businessman of family-run SMEs. For example, management flexibility and relational capability need to be included. Thus, it can continuously improve the financial performance. Another recommendation relates to the research sample; the researcher needs to be more selective in choosing the respondent, considering that their characteristics are very heterogeneous, so it possibly caused biased responses.

\section{References}

Barney, J. (1991). Firm Resources and Sustained Competitive Advantage. Journal of Management, 17(1), 99-120.

Brines, S., Shepherd, D., \& Woods, C. (2013). SME family business innovation: exploring new combinations. Journal of Family Business Management, 3(2), 117-135. doi: 10.1108/jfbm-012012-0002

Carvalho, A. D. P., \& Reis, D. R. D. (2012). Creativity to Innovation in the APL of Information Technology in the Southwest Region of Paraná-PR. The International Journal of Organizational Innovation, 4(3), 7-23. Available at: http://www.ijoi-online.org/ attachments/article/29/Vol4Num3.pdf

Chang, C.-C. (2012). Exploring IT entrepreneurs' dynamic capabilities using Q-technique. Industrial Management \& Data Systems, 112(8), 1201-1216. doi: 10.1108/02635571211264627

Chang, H.-J., \& Wang, H.-B. (2013). A Case Study of Dynamic Competive Advantage The International Journal of Organizational Innovation, 5(4), 30-44. Available at: http:// www.ijoi-online.org/attachments/article/34/FINAL $\% 20$ ISSUE\%20VOL\%205\%20NUM\%204\%20APRIL\%202013. pdf

Chew, D. A. S., Yan, S., \& Cheah, C. Y. J. (2008). Core capability and competitive strategy for construction SMEs in China. Chinese Management Studies, 2(3), 203-214. doi: 10.1108/17506140810895898
Day, G. S. (1994). The capabilities of market-driven organizations. Journal of Marketing, 58(4), 37-52.

Emadzade, M. K., Mashayekhi, B., \& Abdar, E. (2012). Knowledge management capabilities and organizational performance. Interdisciplinary Journal of Contemporary Research in Business, 3(11), 781.

Eris, E. D., \& Ozmen, O. N. T. (2012). The Effect of Market Orientation, Learning Orientation and Innovativeness. International Journal of Economic Sciences and Applied Research, 5(1), 77-108.

Freeze, R. D., \& Kulkarni, U. (2007). Knowledge management capability: defining knowledge assets. Journal of Knowledge Management, 11(6), 94-109. doi: 10.1108/13673270710832190

Garengo, P., \& Bernardi, G. (2007). Organizational capability in SMEs. Performance measurement as a key system in supporting company development. International Journal of Productivity and Performance Management, 56(5/6), 518-532. doi: $10.1108 / 17410400710757178$

Hiebl, M. R. W. (2015). Family involvement and organizational ambidexterity in later-generation family businesses. Management Decision, 53(5), 1061-1082. doi: 10.1108/md-042014-0191

Holtzman, Y. (2008). Innovation in research and development tool of strategic growth. Journal of Management Development, 27(10), 1037-1052. doi: 10.1108/02621710810916295

Hunt, S. D., \& Morgan, R. M. (1995). The comparative advantage theory of competition. Journal of Marketing, 59(2), 1-15.

Jamsa, P. I., Tahtinen, J., Ryan, A., \& Pallari, M. (2011). Sustainable SMEs network utilization : the case of food enterprises. Journal of Small Business and Enterprise Development, 18(1), 141156. doi: $10.1108 / 14626001111106479$

Jaakkola, M., Möller, K., Parvinen, P., Evanschitzky, H., \& Mühlbacher, H. (2010). Strategic marketing and business performance: A study in three European 'engineering countries'. Industrial Marketing Management, 39(8), 13001310. doi: 10.1016/j.indmarman.2010.06.005

Kropp, F., Lindsay, N. J., \& Shoham, A. (2006). Entrepreneurial, market, and learning orientations and international entrepreneurial business venture performance in South African firms. International Marketing Review, 23(5), 504-523. doi: 10.1108/02651330610703427

Lawson-Body, A., \& O'Keefe, T. P. (2006). Interorganizational Relationships B2B. Journal of Electronic Commerce in Organizations, 4(4), 1-21.

Lee, C., Lee, K., \& Penning, J. M. (2001). Internal Capabilities, Eternal Networks, and Performance : A Study on Technology Based Ventures. Strategic Management Journal, 22, 615-640. doi: $10.1002 /$ smj.181

Lin, C.-H., \& Peng, C.-H. (2008). The innovativeness effect of market orientation and learning orientation on business performance. International Journal of Manpower, 29(8), 752772. doi: 10.1108/01437720810919332 
Martinez, V., Radnor, Z., Garengo, P., \& Bernardi, G. (2007). Organizational capability in SMEs: Performance measurement as a key system in supporting company development. International Journal of Productivity and Performance Management, 56(5/6), 518-532.

Mavondo, F. T., Chimhanzi, J., \& Stewart, J. (2005). Learning orientation and market orientation Relationship with innovation, human resource practices and performance. European Journal of Marketing, 39(11/12), 1235-1263. https:// doi.org/10.1108/03090560510623244

Michna, A. (2009). The relationship between organizational learning and SME performance in Poland, Anna Michna, 2009. Journal of European Industrial Training, 33(4), 356-370. doi: 10.1108/03090590910959308

Mikhailitchenko, A., \& Lundstrom, W. J. (2006). Interorganizational relationship strategies and management styles in SMEs. Leadership \& Organization Development Journal, 27(6), 428-448. doi: 10.1108/01437730610687737

Mohd Taisir Masadeh, R., Mohammad Maqableh, M., \& Karajeh, H. (2014). A Theoretical Perspective on the Relationship between Leadership Development, Knowledge Management Capability, and Firm Performance. Asian Social Science, 10(6). doi: 10.5539/ass.v10n6p128

Morgan, N. A., Slotegraaf, R. J., \& Vorhies, D. W. (2009). Linking marketing capabilities with profit growth. Intern. J. of Research in Marketing, 26, 284-293. doi: 10.1016/j.ijresmar.2009.06.005

Nuryakin. (2018). Competitive Advantage and Product Innovation: Key Success of Batik Smes Marketing Performance In Indonesia. Academy of Strategic Management Journal, 17(2), $1-17$.

Nuryakin, \& Ardyan, E. (2018). SMEs' marketing performance: the mediating role of market entry capability. Journal of Research in Marketing and Entrepreneurship, 20(2), 122-146. doi: 10.1108/jrme-03-2016-0005

Nuryakin, Widowati, R., \& Fatmawati, I. (2018). Network Advantage: Mediating Effect on Business Performance. Scientific Annals of Economics and Business, 65(4), 443-457.

Ong, J. W., Ismail, H. B., \& Goh, G. G. G. (2010). The Competitive Advantage of Small and Medium Enterprises (SMEs) The Role of Entrepreneurship and Luck. Journal of Small Business and Entrepreneurship, 23(3), 373-391.

Pérez-Cabañero, C., Camra-Fierro, J., González-Cruz, T., \& Cruz-Ros, S. (2012). Do family SME managers value marketing capabilities' contribution to firm performance? Marketing Intelligence \& Planning, 30(2), 116-142. doi: $10.1108 / 02634501211211948$

Prahalad, C. K., \& Hamel, G. (1994). Competing for the future. New York, NY: Wiley \& Sons.

Raza Bilal, A., Naveed, M., \& Anwar, F. (2017). Linking distinctive management competencies to SMEs' growth decisions. Studies in Economics and Finance, 34(3), 302-330. doi: 10.1108/sef10-2015-0236

Salim, I. M., \& Sulaiman, M. (2011). Organizational Learning, Innovation and Performance A Study of Malaysian Small and Medium Sized Enterprises. International Journal of Business and Management, 6(12), 118-126. doi: 10.5539/ijbm. v6n $12 \mathrm{p} 118$

Singh, R. K., \& Garg, S. K. (2008). Strategy development by SMEs for competitiveness : a review. Benchmarking: An International Journal of Agribusiness in Developing and Emerging Economies, 15(5), 525-547. doi: 10.1108/14635770810903132

Sony, M., \& Naik, S. (2011). Six Sigma, organizational learning and innovation An integration and empirical examination. International Journal of Quality \& Reliability Management, 29(7), 797-818. doi: 10.1108/02656711211258535

Stata, R. (1989). Organizational Learning - The Key to Management Innovation Sloan Management Review, 30(3), 63-74. doi: 10.1108/10569210810907146

Tohidi, H., Seyedaliakbar, S. M., \& Mandegari, M. (2012). Organizational learning measurement and the effect on firm innovation. Journal of Enterprise Information Management Decision, 25(3), 219-245. doi: 10.1108/17410391211224390

Tseng, S.-M., \& Lee, P.-S. (2014). The effect of knowledge management capability and dynamic capability on organizanal performance. Journal of Entreprise Information Management, 27(2), 158-179.

Wang, Y., Watkins, D., Harris, N., \& Spicer, K. (2004). The relationship between succession issues and business performance. International Journal of Entrepreneurial Behavior \& Research, 10(1/2), 59-84. doi: 10.1108/13552550410521380

Yıldız, S., \& Karakaş, A. (2012). Defining Methods and Criteria for Measuring Business Performance: A Comparative Research Between the Literature in Turkey and Foreign. Procedia Social and Behavioral Sciences, 58, 1091-1102. doi: 10.1016/j. sbspro.2012.09.1090 